\title{
STUDY ON PRODUCING HALLOUMI CHEESE FROM DIFFERENT TYPES OF MILK
}

\author{
M.E. El-Demerdash ${ }^{1}$, Sonia A.H. Metwalli ${ }^{2}$ and M.E. Hashem ${ }^{1}$
}

1-Dairy Microbiology Department, Animal Production Research Institute Giza, Egypt, 2- Food Technology Research Institute, Dairy Research Department, Giza, Egypt

\section{SUMMARY}

Halloumi, a traditional cheese in the East Mediterranean region, is popular in the Middle Cyperus, Syria and Lebanon. The aim of this study was to evaluate the chemical, rheological, microbiological and sensory characteristics of four types of Halloumi cheese made from pure cow's milk (T1), pure goat's milk (T2) and their mixtures containing $15 \%$ or $30 \%$ goat's milk (T3, T4). No remarkable differences found in pH, T.S values as well as the total protein of the four types of cheese. In contrast, clear differences in their soluble proteins contents were noted. Rheological examinations showed the hardness and the force at the point of fracture of caprine Halloumi cheese to be lower than those of other types of cheese. The same cheese presented the highest compression at the point of fracture and cohesiveness, while there were no differences in gumminess or chewingness features. Microbiological analysis showed higher total count, yeast and moulds in cheese made from goat's milk. The sensory evaluation showed a preference of Halloumi cheese made from $30 \%$ goat milk and $70 \%$ cow milk.

Keywords: Halloumi cheese, goat milk, cow milk, rheological, sensory evaluation

\section{INTRODUCTION}

Halloumi is a traditional cheese widely popular and produced in Cyprus, and other countries of the Eastern Mediterranean, (Papademas and Robinson, 2001). More recently, Halloumi has gained some international acceptance and recognition. It is a semi hard to hard, un-ripned cheese, elastic, has no obvious skin rind, the texture is closed with no holes and it is easily sliced. Its colour varies from white to yellowish. It can be consumed as raw, but it is usually grilled, fried or grated over a hot dish. Traditionally, ovine and caprine milks, or a mixture of the two in various ratios, were used for the manufacture of Halloumi cheese, but nowadays and due to the increasing demand, local levels of production have had to be raised, and the regulations now permit the manufacture of Halloumi cheese from bovine milk (Papademas and Robinson, 1998). This recent transition towards bovine milk has resulted from the low levels of production of ovine and caprine milk, but it had an impact on the quality of the cheese (Kaminarids et al., 2000). Some consumers have expressed doubts about the ability of this new 'industrial' Halloumi to match the organoleptic quality of the caprine/ovine product.

As Halloumi is a traditional cheese, the manufacturing procedure varies from place to place and this situation created a lot of confusion in terms of which would be the 'correct' procedure (Papademas and Robinson, 1998). This work seeks to further evaluate the textural, physicochemical and organoleptic properties of Halloumi 
cheese prepared from pure cow's milk, pure goat's milk and mixtures containing 15 or $30 \%$ goat milk, with the objective of establishing the optimum percentage of goat milk within the mixture.

\section{MATERIALS AND METHODS}

Materials:

Milk: Fresh cow's and goat's milk were obtained from Sero station, Animal Production Research Institute, Egypt. .

Starters: Streptococcus saliverus spp. thermophulus and Lactobacillus delbrukii spp. Bulgaricus. were obtained from Ch. Hansn's Lab. (Denmark)

Rennet: Calf rennet powder (Ha-La) was obtained from CHR-Hansen's lab. Denmark. Commercial fine grade salt was obtained from El-Nasr Company, Alexandria, Egypt

Methods :

The manufacture of Halloumi cheese has been assessed during a number of studies. Four types of Halloumi cheese were manufactured from unblended cow's milk and goat's milk and from the above two mixtures following the cheese making procedure described by Papademas and Robinson (1991).

\section{Chemical analyses:}

Cheese samples were analysed for fat content Ling (1963), moisture content and titrtable acidity (AOAC, 1990), total ans soluble nitrogen content (IDF 1993). pH according to (Kosikowski, 1977), caseins and lactose (IDF,1987), All analyses were performed in triplicate .

\section{Rheological properties:}

The following textural characteristics were calculated using an Instron Compression Testing Instrument, model 1011 (Instrona, High Wycombe, Bucks, UK) and as described by (Kaminarides et al., 2000) : (i) force at the point of fracture; (ii) hardness, (iii) compression at the point of fracture; (iv) elasticity or springiness (v) cohesiveness (vi) gumminess, and (vii) chewiness. The textural characteristics of the four cheese types were evaluated simultaneously. Five measurements were taken on each, and the mean values and standard error (no statistical analysis was done so, remove the clause "standard error" for the five cheese making trials were determined.

\section{Microbiological analysis:}

Hallomi cheese sampled were examined for total bacterial count was determined according to the method described by IDF (1991), yeast and mould and coliform group detected as described by method of IDF (1985).

\section{Organoleptic evaluation:}

Organoleptic properties of cheese were carried out by a tasting panel of 8 specialized individuals using a scale as suggested by (Kaminarides et al. 2000); all were familiar with Halloumi cheese. Panel members evaluated each cheese for appearance, texture and flavour (odour and taste).

\section{RESULTS AND DISCUSSION}

\section{Chemical composition of milk:}

Table (1) shows the physiochemical characteristics of the four types of milk used for production of Halloumi cheese, where the cow's milk characteristics were in 
agreement with that of Economides et al. (1987) and contains the highest values of most characteristics while the goat's milk were the lowest. The mixtures of both milks showed an intermediate values according to the concentration between these two milks.

Table 1. Chemical composition of milk used for Halloumi cheese

\begin{tabular}{lcccc}
\hline \multirow{2}{*}{ Components } & \multicolumn{4}{c}{ Types of cheese milk } \\
\cline { 2 - 5 } & T1 & T2 & T3 & T4 \\
\hline Total solids \% & 14.18 & 12.38 & 14.0 & 13.24 \\
Fat \% & 3.81 & 3.61 & 3.72 & 0.68 \\
Total protein \% & 5.35 & 3.47 & 5.12 & 4.64 \\
Casein \% & 3.85 & 2.57 & 3.44 & 3.66 \\
Lactose \% & 4.7 & 4.47 & 4.62 & 4.53 \\
pH value & 6.42 & 6.24 & 6.40 & 6.35 \\
Acidity \% & 0.22 & 0.18 & 0.21 & 0.20
\end{tabular}

T1: Cow's milk (100\%), T2: Goat's milk (100\%), T3: Cow's +Goat's milk (85:15\%), T4: Cow's +Goat's milk $(70: 30 \%)$

\section{Chemical composition of cheese:}

Table (2) shows the results of physiochemical characteristics of the produced Halloumi cheese after one day of preparation. As a consequence for the high $\mathrm{pH}$ of cow's milk, the cheese made from $100 \%$ cow's milk shows a slight increase in $\mathrm{pH}$ of resulted cheese while the cheese made from $100 \%$. Goat's milk showed a decrease in $\mathrm{pH}$. Accordingly, the $\mathrm{pH}$ of the mixtures had an $\mathrm{pH}$ intermediate values. The acidity is inversely proportioned to the $\mathrm{pH}$ values of the produced cheese. These results were in agreement with that of Kaminarides et al. (2000). There were remarkable changes in moisture, fat, total protein, ash and $\mathrm{NaCl}$ between the four types and these results are in agreement with that of Cyprus standards for Halloumi cheese (1985).

Table 2. Chemical composition of different types of Halloumi cheese

\begin{tabular}{lcccc}
\hline \multicolumn{1}{c}{ Components } & \multicolumn{4}{c}{ Types of cheese milk } \\
\cline { 2 - 5 } & T1 & T2 & T3 & T4 \\
\hline Fat \% & 30.22 & 30.12 & 30.42 & 30.20 \\
Fat /DM \% & 46.84 & 48.22 & 48.01 & 48.00 \\
Total protein \% & 28.02 & 26.63 & 27.8 & 27.0 \\
Soluble nitrogen \% & 1.21 & 0.83 & 1.04 & 0.91 \\
pH value & 6.43 & 6.15 & 6.32 & 6.24 \\
Acidity \% & 0.15 & 0.20 & 0.16 & 0.18 \\
T.S\% & 60.60 & 59.38 & 59.76 & 59.56 \\
\hline T1: Cow's milk (100\%), T2: Goat's milk $(100 \%)$, T3: Cow's +Goat's milk (85:15\%), T4: Cow's +Goat's \\
milk (70:30\%)
\end{tabular}

The highest soluble protein and non protein nitrogen values were observed in cheese made from $100 \%$ cow's milk (T1), whereas the lowest values were found in cheese made from 100\% goat's milk ( T2). As the percentage of goat milk in the cheese increased, soluble protein and non protein nitrogen values decreased.

Cheese made from milk containing $15 \%$ goat milk had the highest calcium content followed in decline order by the cheese made from $30 \%$ goat milk, $100 \%$ 
cow milk and $100 \%$ goat milk respectively, these might be attributed to the combined effect of calcium concentration of the milk which is higher in cow milk than in goat milk and the average diameter and minerals content of micelles which is higher in goat milk than in cow milk (Remeuf and Lenour, 1986).

\section{Rheological properties of designed cheeses:}

The results of the rheological examinations are presented in Table (3) and showed that the force at the point of fracture and the hardness of cheese made from $100 \%$ goat milk were lower than in the other cheeses which might be due to the lower calcium content as explained by Shaker et al. (1987), contrarily, there were no clear differences between the other three types of cheese. The cheese made from $100 \%$ goat milk was softer and showed a higher value of compression at the point of fracture than that made with other types of milk. The cheese made from $15 \%$ goat milk exhibited a higher elasticity than those made with other types of milk and it is possible that calcium content influenced cheese elasticity. This appears to be in agreement with Prentice et al. (1993). Cheese made from 100\% goat milk had more cohesiveness than the other cheeses, but no obvious differences in gumminess and chewiness were observed.

Table 3. Rheological properties of the different types of Halloumi cheese

\begin{tabular}{lcccc}
\hline Rheological properties & \multicolumn{4}{c}{ Types of cheese milk } \\
\cline { 2 - 5 } & T1 & T2 & T3 & T4 \\
\hline Force at the point of fracture(kg) & 8.36 & 6.89 & 8.06 & 7.84 \\
Hardness (kg) & 10.46 & 8.35 & 9.12 & 8.13 \\
Compression at the point of fracture (\%) & 44.68 & 55.64 & 48.22 & 50 \\
Elasticity (mm) & 6.64 & 7.12 & 6.31 & 7.56 \\
Cohesiveness (kg x mm) & 0.18 & 0.22 & 0.19 & 0.20 \\
Gumminess (kg) & 1.68 & 1.56 & 1.60 & 1.58 \\
Chewingness ( kg x mm) & 10.46 & 12.23 & 11.82 & 13.76 \\
\hline T1: Cow's milk (100\%), T2: Goat's milk (100\%), T3: Cow's +Goat's milk (85:15 \%), T4: Cow's +Goat's \\
milk (70:30\%)
\end{tabular}

\section{Microbiological analysis of cheese:}

The type and flora content of milk play an important role in Halloumi cheese profile and properties (Table 4). However, T2 had higher total bacterial count than other treatments and this could be attributed to the growth and activity of microflora (Ismail, 2008). Yeasts and mould were isolated from Halloumi cheese, particularly from the surface, T2 had the higher counts than other treatments. These results agreed with Anifantakis and Kaminarides et al. (1982).

Table 4. Microbiogical analysis of Halloumi cheese made from different types of milks

\begin{tabular}{lcccc}
\hline Microbiological analysis & \multicolumn{4}{c}{ Types of cheese milk } \\
\cline { 2 - 5 } & T1 & T2 & T3 & T4 \\
\hline Total bacterial count $\times 10^{5}$ & 22.70 & 33.20 & 25.80 & 30.91 \\
Yeast \& moulds $\times 10^{2}$ & 2.20 & 20.40 & 10.60 & 15.30 \\
Coliform & ND & ND & ND & ND \\
\hline T1: Cow's milk (100\%), T2: Goat's milk (100\%), T3: Cow's +Goat's milk (85 :15\%), T4: Cow's +Goat's \\
milk (70 :30\%), ND : Not Detected
\end{tabular}


The presence of yeast and moulds is mainly due to post-contaminations during handling and packaging of the cheese after manufacturing, as the high temperatures during curd cooking the should have killed all yeasts and mould as reported by Anifantakis and Kaminarides (1982). On the other hand, coliform group was not detected in all the produced Halloumi cheese due to the high temperature of curd cooking.

\section{Cheese Organoleptic properties:}

The mean scores of the total organoleptic assessment are presented in table (5), there were pronounced differences between the mean scores for cheese texture and appearance. The cheese made from $100 \%$ goat milk score was lower than the other types of cheeses, which might be due to its unpleasant goaty flavour characteristics. In contrast, there were wide differences between the other three types of cheese, all of which received high scores.

Table 5. Organoleptic evaluation of the different types of Halloumi cheese

\begin{tabular}{lcccc}
\hline \multirow{2}{*}{$\begin{array}{c}\text { Organoleptic } \\
\text { evaluation }\end{array}$} & \multicolumn{4}{c}{ Types of cheese milk } \\
\cline { 2 - 5 } & $\mathbf{T 1}$ & $\mathbf{T 2}$ & $\mathbf{T 3}$ & $\mathbf{T 4}$ \\
\hline Flavour (50) & 35.41 & 32.47 & 36.68 & 40.22 \\
Texture (40) & 31.13 & 30.74 & 33.74 & 34.11 \\
Appearance (10) & 8.02 & 7.72 & 8.23 & 8.62 \\
Total (100) & 74.56 & 70.93 & 78.65 & 82.62 \\
\hline T1: Cow's milk (100\%), T2: Goat's milk (100\%), T3: Cow's +Goat's milk (85:15\%), T4: Cow's +Goat's \\
milk (70:30\%)
\end{tabular}

\section{CONCLUSION}

It can be concluded from this study that all of the cheeses prepared from the four types of milk had a similar composition in the principal components and very good organoleptic scores. Goat Halloumi cheese scored the lowest, whereas cheese made from $30 \%$ goat milk and $70 \%$ cow milk scored the highest. The composition of the cheese influenced the textural characteristics.

\section{REFERENCES}

Anifantakis, E.M. and S.E. Kaminarides, 1982. Contribution to the study of Halloumi cheese made from cow's milk. Journal of Agricultural Research (6) 119-127.

A.O.A.C, 1990. Association of Official Analysis,Chemists. $15^{\text {th }}$ Edition. Association of Analytical Chemists. INC., suite 400, 2200 Wilson Boulevard, Arlington, Virginia 22201, USA.

Cyprus Ministry of Commerce and Industry, 1985. Cyprus Standards, for Halloumi cheese. CYS/TS10. CY 594: parts 1 and 2, Nicosia, Cyprus.

Economides S., E. Geoghiades, A.P. Mavrogenis, 1987. The effect of different milks on the yield and chemical composition of Halloumi cheese. Agricultural research Institute, Ministry of Agriculture and Natural Resources, Nicosia, Cyprus.

IDF “International Dairy Federation”, 1985. Milk and milk products. Enumeration 
of coliforms colony count technique.

IDF, 1987. Milk, cream and evaporated milk-total solids. Standard 21B. Brussels: International Dairy Federation.

IDF, 1991. Milk and milk products. Enumeration of microorganisms colony count technique

IDF, 1993. Milk total nitrogen content. IDF Standard no. 20

Ismail, A.M., 2008. Comparative study in producing Rayeb milk from different types of milk. Egypt. J. of Appli. Sci. 23 (3) 2008 .

Kaminarides, S., E. Rogoti, H. Mallatou, 2000. Comparison of the characteristics of Halloumi cheese made from ovine milk, caprine milk, or mixtures of these milks. International Journal of Dairy Technology,53:100-105

Kosikowski, F., 1977. Cheese and Fermented Milk Foods, 2nd ed. pp 568, 572. Ann Arbor: Edwards Brothers

Ling, E.R., 1963. A Text Book of Dairy Chemistry. Vol. II. Chapman Hall Ltd. London.

Papademas, P. and R.K. Robinson, 1998. Halloumi cheese: the product and its characteristics. . International Journal of Dairy Technology. Vol. 51(3) ,98-103

Papademas P. and R.K. Robinson, 2001. The sensory characteristics of different types of Halloumi cheese as perceived by tasters of different ages. International journal of dairy technology. Vol. 54 (3) ,94-99

Prentice, J.H., K.R. Langley and R.J. Aarshall, 1993. Cheese rheology. In Cheese: Chemistry, Physics and Microbiology, Vol. 1, pp 303-340. Fox P F, ed. London: Chapman and Hall.

Remeuf, F. and J. Lenour, 1986. Relationship between the physic chemical characteristics of goat's milk and its rennet ability. In Ewe's \& goat's milk and milk products. Bulletin No. 202, p 69. Brussels: International Dairy Federation.

Shaker R.R., J. Lelievre and M.W. Taylor, 1987. Manufacture, composition and functional properties of Halloumi cheese from bovine milk. New Zealand. Journal of Dairy Science and Technology 22 181-189. 


\section{دراسة على انتاج الجبن الحلوم من البان مختلفة}

\section{محمد الامرداش' ، سونيا متولى'، محمد هاشم'}

\section{1 - قسم ميكروبيولوجى ألثان، معطُ بحوثِ إلإنتاج الحيواني، r - قسم الألبان، معط تكنولوجيا الأغذية}

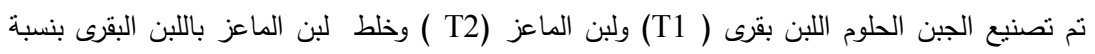

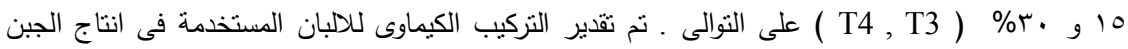

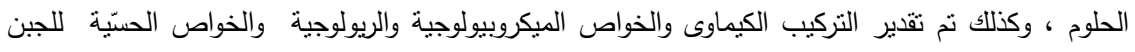

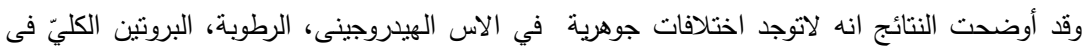

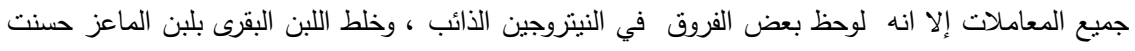

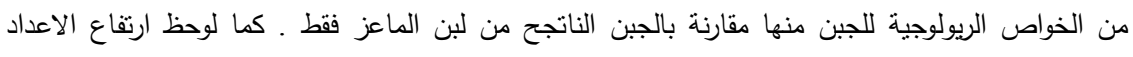

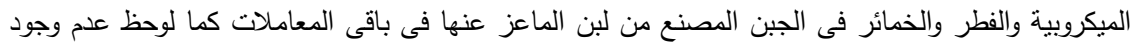

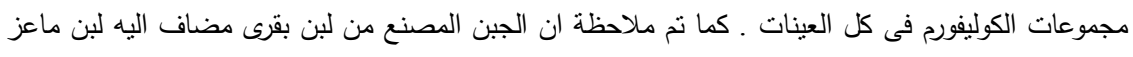

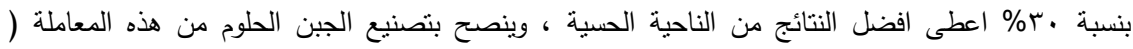

